\title{
Arterial embolization in patients with grade-4 blunt renal trauma: evaluation of the glomerular filtration rates by dynamic scintigraphy with $99 \mathrm{mTechnetium-diethylene}$ triamine pentacetic acid
}

\author{
Seiji Morita*, Sadaki Inokuchi, Tomoatsu Tsuji, Tomokazu Fukushima, Shigeo Higami, \\ Takeshi Yamagiwa, lizuka Shinichi
}

\begin{abstract}
Background: High-grade blunt renal trauma has been treated by arterial embolization (AE). However, it is unknown whether AE preserves renal function, because conventional renal function tests reflect total renal function and not the function of the injured kidney alone. Dynamic scintigraphy can assess differential renal function.

Methods: We performed AE in 17 patients with grade-4 blunt renal trauma and determined their serum creatinine ( $\mathrm{s} C \mathrm{r}$ ) level and glomerular filtration rate (GFR; estimated by dynamic scintigraphy) after 3 months. In 4 patients with low GFR of the injured kidney $\left(<20 \mathrm{ml} \cdot \mathrm{min}^{-1} \cdot 1.73 \mathrm{~m}^{-2}\right)$, the GFR and $\mathrm{s} C r$ were measured again at 6 months. Data are presented as median and interquartile range (25th, 75th percentile).

Results: The median GFR of the injured kidney, total GFR, and median $\mathrm{s} C r$ at 3 months were $29.3(23.7,35.3)$ and $96.8(79.1,102.6) \mathrm{ml} \cdot \mathrm{min}^{-1} \cdot 1.73 \mathrm{~m}^{-2}$ and $0.6(0.5,0.7) \mathrm{mg} / \mathrm{dl}$, respectively. In the patients with low GFR $\left(\mathrm{ml}^{\prime} \cdot \mathrm{min}^{-1} \cdot 1.73\right.$ $\left.\mathrm{m}^{-2}\right)$, the median GFR of the injured kidney, total GFR, and median $\mathrm{sCr}(\mathrm{mg} / \mathrm{dl})$ were $16.2(15.7,16.3), 68.7(61.1$,

71.6), and $0.7(0.7,0.9)$, respectively, at 3 months and $34.5(29.2,37.0), 90.9(79.1,98.8)$, and $0.7(0.7,0.8)$, respectively, at 6 months.
\end{abstract}

Conclusions: The function of the injured kidney was preserved in all patients, indicating the efficacy of AE for the treatment of grade-4 blunt renal trauma.

\section{Background}

Some recent studies have suggested that high-grade renal trauma can be successfully treated by non-operative management (NOM), which includes conservative management and arterial embolization (AE) [1-4]. In these studies, it was emphasized that NOM for highgrade renal trauma is less invasive than nephrectomy, and unlike nephrectomy, it preserves the renal function of the injured kidney. In most of these studies, renal function was assessed on the basis of the serum creatinine $(\mathrm{sCr})$ level; serum blood urea nitrogen (BUN) level;

\footnotetext{
* Correspondence: morita@is.icc.u-tokai.ac.jp

Department of Emergency and Critical Care Medicine, Tokai University School of Medicine, 143 Shimokasuya Isehara-City, Japan
}

and creatinine clearance $\left(\mathrm{CCr}_{24} \mathrm{~h}\right)$, which was determined from a 24-h urine sample. These parameters do not reflect the function of the injured kidney, but the total renal function (i.e., the function of both the injured and the contralateral uninjured kidney). Dynamic scintigraphy can determine the differential renal function.

We hypothesized that $\mathrm{AE}$ for severe blunt renal trauma could preserve the renal function of the injured kidney. Therefore, we used dynamic scintigraphy with ${ }^{99} \mathrm{~m}_{\text {techne- }}$ tium (Tc)-labeled diethylene triamine pentaacetic acid (DTPA) to evaluate renal function in patients with grade-4 blunt renal trauma (American Association for the Surgery of Trauma; AAST [5] after they had undergone AE. 


\section{Methods}

Between April 2003 and March 2008, we treated 28 patients with grade- 4 blunt renal trauma (AAST) in Tokai University School of Medicine Emergency Center. Of these 28 patients, 6 underwent conservative management because extravasation of the contrast medium was not observed on computed tomography (CT), 21 underwent angiography and $\mathrm{AE}$ because extravasation of the contrast medium was observed on CT and angiography, and 1 underwent emergency nephrectomy because hemodynamic instability was present. In 17 of the 21 patients who underwent $\mathrm{AE}$, the glomerular filtration rate (GFR) of the injured kidney was evaluated by dynamic scintigraphy at 3 months after the injury. Dynamic scintigraphy could not be performed in the remaining 4 patients because 3 of them died from multiple trauma and 1 patient refused treatment. In 4 of the 17 patients who underwent dynamic scintigraphy, the GFR of the injured kidney was less than $20 \mathrm{ml} \cdot \mathrm{min}^{-1} \cdot 1.73 \mathrm{~m}^{-2}$. In these patients, dynamic scintigraphy was repeated at 6 months after the injury.

Our case series included the 17 patients with grade- 4 blunt renal trauma who underwent $\mathrm{AE}$ and whose renal function was evaluated by dynamic scintigraphy with ${ }^{99}$ ${ }^{\mathrm{m}}$ Tc-DTPA at 3 months after the injury. In this case series, we report on detailed characteristics of these patients and examine whether renal function can be preserved by performing AE. Renal function was assessed on the basis of the GFR of the injured kidney, the contralateral uninjured kidney, and both kidneys (as estimated by dynamic scintigraphy) and sCr. In the case of the 4 patients who underwent dynamic scintigraphy at 3 and 6 months after the injury, we compared their GFR and sCr levels at these 2 time points. Data are presented as median and interquartile range (25th, 75 th percentile).

In our institution, blunt abdominal trauma patients who are hemodynamically stable, with or without fluid resuscitation, undergo abdominal CT. If CT reveals grade-4 renal trauma with extravasation of the contrast medium, we perform emergency angiography. If angiography reveals extravasation of the contrast medium from the kidney, selective embolization or superselective embolization is performed using a microcatheter and either gelatin particles or steel coils or both.

This study was approved by our hospital's Institutional Ethics Committee.

\section{Results}

The detailed patient characteristics are presented in Table 1 . Of the 17 patients, 14 were male; 9 patients were involved in a traffic accident, 4 sustained an injury during fall, 2 were victims of violence, and 2 sustained sports injuries. The median age of the patients was 35 $(23,41)$ years. The left kidney was injured in 10 patients; 1 patient had renal dysfunction due to diabetes mellitus, while the other patients had no relevant medical history. The median injury severity score (ISS) was $24(16,29)$. Ten patients had multiple trauma. AE was performed with gelatin particles (10 patients) or steel coils (3 patients) or both (4 patients). All patients survived and none experienced a recurrence of renal bleeding.

The renal function at 3 months resented in Table 2. The median GFRs of the injured kidney, the contralateral

Table 1 Characteristics of the 17 patients

\begin{tabular}{|c|c|c|c|c|c|c|c|c|}
\hline $\begin{array}{l}\text { Patient's } \\
\text { number }\end{array}$ & Sex & $\begin{array}{c}\text { Age } \\
\text { (years old) }\end{array}$ & $\begin{array}{l}\text { Injured } \\
\text { kidney }\end{array}$ & $\begin{array}{l}\text { Cause of } \\
\text { injury }\end{array}$ & $\begin{array}{l}\text { Medical past } \\
\text { history }\end{array}$ & ISS & Other major injuries & $\begin{array}{c}\text { Embolization } \\
\text { technique } \\
\text { and materials }\end{array}$ \\
\hline 1. & $\mathrm{~F}$ & 23 & $L$ & T/A & - & 29 & Thoracic injury, Facial injury & SSE GP \\
\hline 2. & M & 25 & $L$ & Fall & - & 24 & Thoracic injury, Limb Fx & SSE GP \\
\hline 3. & M & 26 & $L$ & $\mathrm{~T} / \mathrm{A}$ & - & 24 & Thoracic injury, Limb Fx & SSE GP+SC \\
\hline 4. & $\mathrm{~F}$ & 45 & $L$ & $\mathrm{~T} / \mathrm{A}$ & - & 29 & Thoracic injury, Limb Fx & SE SC \\
\hline 5. & M & 18 & $\mathrm{R}$ & Sports & - & 16 & - & SSE GP \\
\hline 6. & M & 52 & $\mathrm{R}$ & Sports & DM & 16 & - & SSE GP \\
\hline 7. & M & 37 & $\mathrm{R}$ & $\mathrm{T} / \mathrm{A}$ & - & 24 & Head injury, thoracic injury & SE SC \\
\hline 8. & $M$ & 36 & $\mathrm{R}$ & Violence & - & 16 & - & SSE GP \\
\hline 9 & $M$ & 16 & $\mathrm{R}$ & Fall & - & 36 & Head injury, Pelvic Fx & SSE GP+SC \\
\hline 10. & $M$ & 25 & $L$ & $\mathrm{~T} / \mathrm{A}$ & - & 16 & - & SSE GP \\
\hline 11. & M & 52 & $L$ & Fall & - & 34 & Thoracic injury, Pelvic Fx & SSE GP \\
\hline 12. & $M$ & 19 & $L$ & $\mathrm{~T} / \mathrm{A}$ & - & 16 & - & SSE GP+SC \\
\hline 13. & $M$ & 41 & $L$ & $\mathrm{~T} / \mathrm{A}$ & - & 16 & - & $\mathrm{SE} G \mathrm{G}+\mathrm{SC}$ \\
\hline 14. & $M$ & 35 & $\mathrm{R}$ & Fall & - & 24 & Pelvic Fx, Limb Fx & SSE GP \\
\hline 15. & $M$ & 52 & $L$ & $\mathrm{~T} / \mathrm{A}$ & - & 24 & Head injury, Thoracic injury & SE SC \\
\hline 16. & M & 38 & $\mathrm{R}$ & $\mathrm{T} / \mathrm{A}$ & - & 16 & - & SSE GP \\
\hline 17. & $\mathrm{~F}$ & 23 & $L$ & Violence & - & 29 & Head injury, Thoracic injury & SSE GP \\
\hline
\end{tabular}

F: female, M: male, L: left, R: right, T/A: traffic accident, DM: diabetes mellitus, Fx: fracture, SE: selective embolization, 
Table 2 Renal function of the 17 patients at 3 months

\begin{tabular}{|c|c|c|c|c|}
\hline \multirow[b]{2}{*}{ Patient's number } & \multicolumn{3}{|c|}{ GFR at 3 months $\left(\mathrm{ml} \cdot \mathrm{min}^{-1} \cdot 1.73 \mathrm{~m}^{-2}\right)$} & \multirow[b]{2}{*}{$\mathrm{sCr}$ at 3 months $(\mathrm{mg} / \mathrm{dl})$} \\
\hline & Injured kidney & Uninjured kidney & Both kidneys & \\
\hline 1. & 29.3 & 49.8 & 79.1 & 0.4 \\
\hline 2. & 39.2 & 59.4 & 98.6 & 0.6 \\
\hline 3. & 14.9 & 51.5 & 66.4 & 0.7 \\
\hline 4. & 16.0 & 57.7 & 73.6 & 0.7 \\
\hline 5. & 36.0 & 60.8 & 96.8 & 0.9 \\
\hline 6. & 16.3 & 28.8 & 45.1 & 1.6 \\
\hline 7. & 37.1 & 46.3 & 83.4 & 0.5 \\
\hline 8. & 26.4 & 76.2 & 102.6 & 0.6 \\
\hline 9. & 33.0 & 55.1 & 88.1 & 0.5 \\
\hline 10. & 16.4 & 54.5 & 70.9 & 0.5 \\
\hline 11. & 35.3 & 63.7 & 99.0 & 0.7 \\
\hline 12. & 28.6 & 74.2 & 102.8 & 0.4 \\
\hline 13. & 37.5 & 67.8 & 105.3 & 0.6 \\
\hline 14. & 23.7 & 89.6 & 113.3 & 0.5 \\
\hline 15. & 27.6 & 73.9 & 101.5 & 0.8 \\
\hline 16. & 34.2 & 81.4 & 115.6 & 0.7 \\
\hline 17. & 30.2 & 57.5 & 87.7 & 0.6 \\
\hline
\end{tabular}

uninjured kidney, and both kidneys at 3 months were 29.3 (23.7, 35.3), $59.4(54.5,73.9)$, and 96.8 (79.1, 102.6) $\mathrm{ml} \cdot \mathrm{min}^{-1} \cdot 1.73 \mathrm{~m}^{-2}$, respectively. The median $\mathrm{sCr}$ was 0.6 $(0.5,0.7) \mathrm{mg} / \mathrm{dl}$. In patients $3,4,6$, and 10 (as listed in Table 1), the GFR of the injured kidney was less than 20 $\mathrm{ml} \cdot \mathrm{min}^{-1} \cdot 1.73 \mathrm{~m}^{-2}$ at 3 months. The GFR and $\mathrm{sCr}$ levels of these 4 patients at 3 and 6 months are presented in Table 3. Of these 4 patients, 3 were male; their median age was $35.5(25.8,46.8)$ years. For these 4 patients, the median GFRs of the injured kidney, contralateral uninjured kidney, and both kidneys at 3 months were 16.2 $(15.7,16.3), 53.0(45.8,55.3)$, and $68.7(61.1,71.6)$ $\mathrm{ml} \cdot \mathrm{min}^{-1} \cdot 1.73 \mathrm{~m}^{-2}$, respectively, and the median $\mathrm{sCr}$ level was $0.7(0.7,0.9) \mathrm{mg} / \mathrm{dl}$. For these 4 patients at 6 months, the median GFRs of the injured kidney, contralateral uninjured kidney, and both kidneys were 34.5 (29.2, 37.0), $55.5(45.4,65.4)$, and $90.9(79.1,98.8) \mathrm{ml} \cdot \mathrm{min}^{-1} \cdot 1.73 \mathrm{~m}^{-2}$, respectively, and the median $\mathrm{sCr}$ level was $0.7(0.7,0.8)$ $\mathrm{mg} / \mathrm{dl}$. The GFRs of the injured kidney and both kidneys improved.

\section{Discussion}

Conservative management has become the standard treatment for patients with blunt renal trauma (AAST grades 1 to 3) who are hemodynamically stable [1-4]. Most experts agree that surgical exploration is required in patients with grade- 5 blunt renal trauma. The management of patients with grade- 4 blunt renal trauma, however, remains controversial [6-8]. Although ideally the surgical management of patients with severe blunt renal trauma should entail renal reconstruction, nephrectomy is required in majority of such patients. Hemodynamic instability in patients with blunt renal trauma is the most likely indication for nephrectomy, which is the most expeditious surgical option in this scenario. It is reported that nephrectomy is performed in 43-75\% of patients who undergo emergency laparotomy for severe blunt renal injury $[9,10]$. Nephrectomy is the intentional removal of a kidney and necessarily results in partial loss of renal function. Therefore, unless nephrectomy is absolutely indicated, it constitutes an unacceptable infliction of iatrogenic injury.

Table 3 Glomerular filtration rates at 3 and 6 months

\begin{tabular}{|c|c|c|c|c|c|c|c|c|}
\hline \multirow[b]{2}{*}{$\begin{array}{l}\text { Patient's } \\
\text { number }\end{array}$} & \multicolumn{3}{|c|}{ GFR at 3 months $\left(\mathrm{ml} \cdot \mathrm{min}^{-1} \cdot 1.73 \mathrm{~m}^{-2}\right)$} & \multirow[b]{2}{*}{$\begin{array}{c}\mathrm{sCr} \text { at } 3 \text { months } \\
(\mathrm{mg} / \mathrm{dl})\end{array}$} & \multicolumn{3}{|c|}{ GFR at 6 months $\left(\mathrm{ml} \cdot \mathrm{min}^{-1} \cdot 1.73 \mathrm{~m}^{-2}\right)$} & \multirow[b]{2}{*}{$\begin{array}{l}\mathrm{sCr} \text { at } 6 \text { months } \\
(\mathrm{mg} / \mathrm{dl})\end{array}$} \\
\hline & $\begin{array}{l}\text { Injured } \\
\text { kidney }\end{array}$ & $\begin{array}{c}\text { Uninjured } \\
\text { kidney }\end{array}$ & $\begin{array}{c}\text { Both } \\
\text { kidneys }\end{array}$ & & $\begin{array}{c}\text { Injured } \\
\text { kidney }\end{array}$ & $\begin{array}{c}\begin{array}{c}\text { Uninjured } \\
\text { kidney }\end{array} \\
\end{array}$ & $\begin{array}{c}\text { Both } \\
\text { kidneys }\end{array}$ & \\
\hline 3. & 14.9 & 51.5 & 66.4 & 0.7 & 38.4 & 50.5 & 88.9 & 0.7 \\
\hline 4. & 16.0 & 57.7 & 73.6 & 0.7 & 32.4 & 60.4 & 92.8 & 0.7 \\
\hline 6. & 16.3 & 28.8 & 45.1 & 1.6 & 19.4 & 30.2 & 49.6 & 1.0 \\
\hline 10. & 16.4 & 54.5 & 70.9 & 0.5 & 36.5 & 80.2 & 116.7 & 0.5 \\
\hline
\end{tabular}


In many recent studies, high success rates have been obtained with NOM, which includes conservative management and $\mathrm{AE}$, of patients with high-grade blunt renal trauma [1-4]. NOM is therefore gradually becoming the recommended clinical treatment for high-grade blunt renal trauma, particularly in the case of hemodynamically stable patients. Although it is known that conservative management of patients with high-grade blunt renal trauma allows the injured kidney to be preserved and obviates the need for nephrectomy, it has remained unclear whether conservative management preserves the function of the injured kidney. This is because most previous studies have assessed renal function after $\mathrm{NOM}$ on the basis of the $\mathrm{sCr}$ and BUN levels and $\mathrm{CCr}_{24} \mathrm{~h}$ [1-4]. Levels of sCr and BUN are poor indicators of the function of the injured kidney, because the contralateral uninjured kidney can maintain normal serum concentrations of these markers. $\mathrm{CCr}_{24} \mathrm{~h}$ reflects the total renal function and not the function of the injured kidney alone. We consider radionuclide scanning to be a suitable examination for directly evaluating the function of the injured kidney, because it is the only examination that can assess differential renal function.

A few studies have used dynamic scintigraphy with ${ }^{99} \mathrm{~m}$ Tc-dimercaptosuccinic acid (DMSA) for the morphological evaluation of the injured kidney [11-13]. By performing radionuclide renography and scintigraphy, Wessells et al. quantified the degree of preservation of renal function after reconstruction for traumatic renal injury (grades 2-5) [11]. They used ${ }^{99} \mathrm{~m}$ Tc-DMSA and evaluated the function of the injured kidney on the basis of the uptake percentage. They defined adequate renal preservation as the salvage of more than one third of the injured kidney and reported that adequate preservation was achieved in $81 \%$ of their patients. By performing $99 \mathrm{~m}$ Tc-DMSA scintigraphy and CT angiography, El-Sherbiny et al. evaluated renal function and morphology long after conservative management in children with severe renal trauma [12]. They found no significant functional loss in any of the affected kidneys (split renal function, 41-50\%).

Recent advances in radiological techniques such as CT and echography now allow these techniques to be used for the morphological evaluation of renal trauma patients; therefore, ${ }^{99} \mathrm{~m}$ Tc-DMSA scintigraphy is not frequently used for this purpose. Compared to dynamic studies with ${ }^{99}$ mc-DMSA, those with agents such as $99 \mathrm{~m}_{\mathrm{Tc}} \mathrm{c}$-diethylenetriamine pentaacetic acid (DTPA), ${ }^{131} \mathrm{I}$ - and ${ }^{123} \mathrm{I}$-ortho-iodohippurate $(\mathrm{OIH})$, and ${ }^{99} \mathrm{~m} \mathrm{Tc}$ mercaptoacetyl-glycyl-glycyl-glycine $\left(\mathrm{MAG}_{3}\right)$ provide more information about differential renal function; in addition to GFR, the effective renal plasma flow (ERPF) can be calculated as a differential renal function.

In our case series, the median GFR of the injured kidney and the median $\mathrm{sCr}$ level at 3 months after the injury were $29.3(23.7,35.3) \mathrm{ml} \cdot \mathrm{min}^{-1} \cdot 1.73 \mathrm{~m}^{-2}$ and 0.6 $(0.5,0.7) \mathrm{mg} / \mathrm{dl}$, respectively. Further, the median GFR of both kidneys at 3 months was 96.8 (79.1, 102.6) $\mathrm{ml} \cdot \mathrm{min}^{-1} \cdot 1.73 \mathrm{~m}^{-2}$. We therefore believe that adequate preservation of the function of the injured kidney was achieved. In the 4 patients in whom the GFR of the injured kidney was less than $20 \mathrm{ml} \cdot \mathrm{min}^{-1} \cdot 1.73 \mathrm{~m}^{-2}$, the median GFRs of the injured kidney and both kidneys at 3 months were $16.2(15.7,16.3)$ and $68.7(61.1,71.6)$ $\mathrm{ml} \cdot \mathrm{min}^{-1} \cdot 1.73 \mathrm{~m}^{-2}$, respectively. This shows that adequate preservation of renal function was not achieved at 3 months. However, at 6 months, the GFRs of the injured kidney and both kidneys improved and were $34.5(29.2,37.0)$ and $90.9(79.1,98.8) \mathrm{ml} \cdot \mathrm{min}^{-1} \cdot 1.73 \mathrm{~m}^{-2}$, respectively. The GFR of both kidneys at 6 months was almost in the normal range. In patient 6 , who had diabetic nephropathy before injury, the GFRs at 3 and 6 months did not show improvement. This suggests that blunt renal trauma patients with preexisting chronic kidney diseases may require careful long-term follow-up after AE. Furthermore, Wessells et al. reported that blunt renal trauma patients who develop hypotension in their clinical course experience significant renal dysfunction [11].

\section{Conclusions and Limitation}

In our case series, AE in grade-4 blunt renal trauma patients resulted in the adequate preservation of renal function at 3 or 6 months after injury. This outcome suggests that $\mathrm{AE}$ is efficacious for the treatment of patients with grade- 4 blunt renal trauma. However, because our research was a case series $(n=17)$, it does not provide enough evidence to prove this association. Further research, with a large number of patients should be conducted in future to examine this concept in more depth.

\section{Acknowledgements}

We thank Mitsuhiro Isozaki for advising statistical methods.

\section{Authors' contributions}

SM conceived of this study, performed the analysis and prepared the manuscript

$\Pi$, TF, SH, TY, IS contributed to the study design and prepared the figures. SI participated as expert instructors, contributed to the study design.

All authors read and approved the final manuscript.

\section{Competing interests}

The authors declare that they have no competing interests.

Received: 22 November 2009

Accepted: 7 March 2010 Published: 7 March 2010

\section{References}

1. Iqbal $\mathrm{N}$, Chughtai MN: Management of blunt renal trauma: A profile of 65 patients. J Pak Med Assoc 2004, 54:516-518.

2. Toutouzas KG, Karaiskakis M, Kaminski A, Velmahos GC: Nonoperative management of blunt renal trauma: A prospective study. Am Surg 2002, 12:1097-1103. 
3. Schmidlin FR, Rohner S, Hadaya K: The conservative treatment of major kidney injuries. Am Urol 1997, 31:246-252.

4. Hagiwara A, Sakaki S, Goto H, Takenega K, Fukushima H, Matuda H, Shimazaki S: The role of interventional radiology in the management of blunt renal injury: A practical protocol. J Trauma 2001, 51:526-531.

5. Moore EE, Shackford SR, Pachter HL, McAninch JW, Browner BD, Champion HR, Flint LM, Gennarelli TA, Malangoni MA, Ramenofsky ML, Trafton PG: Organ injury scaling: Spleen, liver, and kidney. J Trauma 1989, 29:1664-1666.

6. Henderson CG, Sedberry-Ross S, Pickard R, Bulas DI, Duffy BJ, Tsung D, Eichelberger MR, Belman AB, Rushton HG: Management of high grade renal trauma: 20-year experience at a pediatric level I trauma center. I Urol 2007, 178:246-250.

7. Buckley JC, MCAninch JW: Selective management of isolated and nonisolated grade IV renal injuries. J Urol 2006, 176:2498-2502.

8. Hammer CC, Santucci RA: Effect of an institutional policy of nonoperative treatment of grades I to IV renal injuries. J Urol 2003, 169:1751-1753.

9. Bozeman C, Carver B, Zabari G, Caldito G, Venable D: Selective operative management of major blunt renal trauma. J Trauma 2004, 57:305-309.

10. Kristjanson A, Pederson J: Management of blunt renal trauma. Br J Urol 1993, 72:692-696.

11. Wessells H, Deirmenjian J, MCAninch JW: Preservation of renal function after reconstruction for trauma: Quantitative assessment with radionuclide scintigraphy. J Urol 1997, 157:1583-1586.

12. El-Sherbiny MT, Aboul-Ghar ME, Hafez AT, Hammad AA, Bazeed MA: Late renal functional and morphological evaluation after non-operative treatment of high-grade renal injuries in children. BJU Int 2004, 93:1053-1056

13. Moog R, Becmeur F, Dutson E, Chevaliner-Kauffmann I, Sauvage P, Brunot B: Functional evaluation by quantitative dimercaptosuccinic acid scintigraphy after kidney trauma in children. J Urol 2003, 169:641-644.

doi:10.1186/1757-7241-18-11

Cite this article as: Morita et al:: Arterial embolization in patients with grade-4 blunt renal trauma: evaluation of the glomerular filtration rates by dynamic scintigraphy with $99 \mathrm{mTechnetium-diethylene} \mathrm{triamine}$ pentacetic acid. Scandinavian Journal of Trauma, Resuscitation and Emergency Medicine 2010 18:11.

\section{Submit your next manuscript to BioMed Central and take full advantage of:}

- Convenient online submission

- Thorough peer review

- No space constraints or color figure charges

- Immediate publication on acceptance

- Inclusion in PubMed, CAS, Scopus and Google Scholar

- Research which is freely available for redistribution

Submit your manuscript at www.biomedcentral.com/submit
Biomed Central 